\title{
Polymorphisms in FGFBP1 and FGFBP2 genes associated with carcass and meat quality traits in chickens
}

\author{
A.M. Felício ${ }^{1}$, C. Boschiero ${ }^{2}$, J.C.C. Balieiro ${ }^{3}$, M.C. Ledur ${ }^{4}$, J.B.S. Ferraz ${ }^{3}$, \\ A.S.A.M.T. Moura ${ }^{5}$ and L.L. Coutinho ${ }^{1}$ \\ ${ }^{1}$ Departamento de Zootecnia, Escola Superior de Agricultura Luiz de Queiroz, \\ Universidade de São Paulo, Piracicaba, SP, Brasil \\ ${ }^{2}$ Roslin Institute, Royal (Dick) School of Veterinary Studies, \\ University of Edinburgh, Midlothian, Edinburgh, Scotland \\ ${ }^{3}$ Departamento de Ciências Básicas, \\ Faculdade de Zootecnia e Engenharia de Alimentos, \\ Universidade de São Paulo, Pirassununga, SP, Brasil \\ ${ }^{4}$ Embrapa Suínos e Aves, Concórdia, SC, Brasil \\ ${ }^{5}$ Departamento de Produção Animal, \\ Faculdade de Medicina Veterinária e Zootecnia, \\ Universidade Estadual Paulista, Rubião Júnior, Botucatu, SP, Brasil
}

Corresponding author: L.L. Coutinho

E-mail:1lcoutinho@usp.br

Genet. Mol. Res. 12 (1): 208-222 (2013)

Received May 3, 2012

Accepted August 27, 2012

Published January 24, 2013

DOI http://dx.doi.org/10.4238/2013.January.24.13

\begin{abstract}
In the past, the focus of broiler breeding programs on yield and carcass traits improvement led to problems related to meat quality. Awareness of public concern for quality resulted in inclusion of meat quality traits in the evaluation process. Nevertheless, few genes associated with meat quality attributes are known. Previous studies mapped quantitative trait loci for weight at 35 and 42 days in a region of GGA4 flanked by the microsatellite markers, MCW0240 and LEIO063. In this region, there are 2 fibroblast growth factor binding protein $(F G F B P)$ genes that play an important role in embryogenesis, cellular
\end{abstract}


differentiation, and proliferation in chickens. The objective of this study was to identify and associate single nucleotide polymorphisms (SNPs) in FGFBP1 and FGFBP2 with performance, carcass, and meat quality in experimental and commercial chicken populations. In the commercial population, SNP g.2014G $>$ A in $F G F B P 1$ was associated with decreased carcass weight $(\mathrm{P}<0.05)$, and SNP g. $651 \mathrm{G}>\mathrm{A}$ in $F G F B P 2$ was associated with thawing loss and meat redness content $(\mathrm{P}<0.05)$. Four haplotypes were constructed based on 2 SNPs and were associated with breast weight, thawing loss, and meat redness content. The diplotypes were associated with thawing loss, lightness, and redness content. The SNPs evaluated in the present study may be used as markers in poultry breeding programs to aid in improving growth and meat quality traits.

Key words: Breeding; Fibroblast; Growth; QTL; SNP

\section{INTRODUCTION}

The increasing world population, as well as the greater purchasing power of lowincome individuals, have resulted in a growing demand for animal products. To meet this demand, the industry, particularly the poultry industry, has improved productivity rates mainly through genetic improvement (Yang et al., 1999).

Until recently, broiler breeding programs were primarily focused on performance and carcass traits. However, this focus has resulted in meat quality-related problems (Anthony, 1998; Dransfield and Sosnicki, 1999) and has led to the inclusion of quality traits in breeding programs. This change has been observed in both the meat-processing industry and end consumers who are increasingly concerned and demanding in terms of meat quality-related traits (Park et al., 2002).

Changes in meat quality may occur due to the correlation between yield and quality traits. Dransfield and Sosnicki (1999) reported that selection for increased chicken breast weight tends to raise pale, soft, and exudative meat incidence in chickens. These results differed from those of Le Bihan-Duval et al. (2008) who found high and negative genetic correlations between breast yield and dripping and cooking losses $(-0.65 \pm 0.10$ and $-0.80 \pm 0.06$, respectively) in chickens. Gaya et al. (2011) found a moderate and negative genetic correlation $(-0.42 \pm 0.12)$ between breast weight and thawing-cooking loss, indicating that selection for increased breast weight could improve the water-holding capacity of chicken.

Advances in molecular genetics have generated new tools to identify genomic regions and alleles involved in traits of economic interest (Dekkers, 2004). Numerous quantitative trait loci (QTL) have been mapped for performance and carcass traits in different chromosomes (http:// www.animalgenome.org/QTLdb/chicken.html). In a previous study, Ambo et al. (2009), working with an experimental $\mathrm{F}_{2}$ population derived from a cross between a layer and a broiler line from Embrapa, mapped a QTL for body weight at 35 and 42 days between microsatellite markers MCW0240 (198.7 cM) and LEIO063 $(235.2 \mathrm{cM})$ in chicken chromosome 4. In a different study with the same population, Baron et al. (2010) mapped a QTL for percentage of thighs and drumsticks in the same region of chromosome 4. The study of this QTL region allowed the identification of 2 candidate genes potentially associated with traits of economic interest: fibroblast growth factor binding protein 1 (FGFBP1) and fibroblast growth factor binding protein 2 (FGFBP2). 
FGFBP1 (also known as HBP17) binds to fibroblast growth factors (FGFs) such as $F G F 1$ and $F G F 2$ (Wu et al., 1991), as well as $F G F 7,10$, and 22 (Beer et al., 2005). Studies report that $F G F B P 1$ is able to mobilize $F G F 2$ from the extracellular matrix and improve biological activities of $F G F 1$ and $F G F 2$ (Aigner et al., 2001; Tassi et al., 2001). FGF2 plays an essential role in regulating differentiation, proliferation, and apoptosis of osteoblasts in humans (Marie et al., 2002).

$F G F B P 2$ is highly expressed in malignant cells in humans and in normal tissues (Marie et al., 2002). A previous study showed that FGFBP1 and FGFBP2 are related to embryogenesis in chickens and contribute to chicken development (Gibby et al., 2009).

In chickens, the FGFBP1 gene presents 1182 bp divided into 2 exons and 208 amino acids; the $F G F B P 2$ gene has 980 bp distributed into 2 exons and encodes a protein with 307 amino acids. The FGFBP 1 and $F G F B P 2$ genes have 34 and 21 single nucleotide polymorphisms (SNPs), respectively, described in the public chicken database, dbSNP (2012). However, there are no studies regarding the identification and association of SNPs in the FGFBP1 and $F G F B P 2$ genes for traits of economic interest in poultry.

This study aimed to 1) identify polymorphisms in the FGFBP1 and FGFBP2 candidate genes, 2) study the association of these SNP with traits of performance, carcass, muscle development, and meat quality in experimental and commercial poultry populations.

\section{MATERIAL AND METHODS}

\section{Populations}

In this study, we used an experimental $\mathrm{F}_{2}$ population (Embrapa Swine and Poultry) and a commercial population. The experimental population was an $\mathrm{F}_{2}$ (TCTC) line developed by Embrapa Swine and Poultry through crosses between males from a broiler line (TT) and females of the egg-laying line (CC). CC originates from the White Leghorn breed, whose breeding program aimed to improve egg production, egg weight, sexual maturity, fertility, hatchability, egg quality, feed conversion, viability, and reduced body weight. TT originates from White Plymouth Rock, New Hampshire, and White Cornish breeds, which were bred to improve feed conversion, body weight, carcass, and breast yield, fertility, viability, reduced abdominal fat, and metabolic syndromes (ascites and sudden death). Rosário et al. (2009) previously described further details of the 2 lines (TT and CC).

The commercial population used for this study was an elite male broiler line obtained from a breeding company. Details of the commercial population were previously described by Gaya et al. $(2006,2011)$.

\section{Phenotypes and DNA extraction}

In the $\mathrm{F}_{2}$ experimental population from Embrapa, we evaluated body weight at 35 days (BW35), body weight at 41 days (BW41), body weight at 42 days (BW42), feet weight (feet), weight of drums and thighs (drums and thighs), breast weight with skin and bones (breast), carcass weight (sum of carcass parts; carcass), crude protein in grams (protein), and ash in grams (ash). The details of the description of the chemical composition are described in the previous report by Nones et al. (2012). 
Genomic DNA of $F_{1}$ and $F_{2}$ chickens from the experimental populations was extracted from blood samples using the DNAzol reagent (Life Technologies, Carlsbad, CA, USA).

The following characteristics were evaluated in the commercial population: selection body weight, slaughter body weight, eviscerated carcass weight (EBW), breast weight (BRT), leg weight, $\mathrm{pH} 24 \mathrm{~h}$ after slaughter (final $\mathrm{pH}$ ), color values measured $24 \mathrm{~h}$ after slaughter [parameters: L* (lightness), a* (redness), $\mathrm{b}^{*}$ (yellowness)], drip loss, thawing loss, thawingcooking loss (TCL), total water loss, muscle fibers of diameter, muscle fibers of areas, muscle fiber number per histological field, and shear force. These traits were evaluated in the pectoralis major muscle in the skull-ventral portion.

Genomic DNA was extracted from histological sections of muscle tissue embedded in paraffin using a lysis solution $(200 \mathrm{mM} \mathrm{NaOH})$ and a neutralizing solution $(200 \mathrm{mM} \mathrm{HCl}, 100$ $\mathrm{mM}$ Tris- $\mathrm{HCl}, \mathrm{pH} 8.5$ ). The samples were labeled and stored at $-18^{\circ} \mathrm{C}$.

\section{Selection of candidate genes}

The candidate genes $F G F B P 1$ and $F G F B P 2$ were selected since they are located in a region of chicken chromosome 4 in which QTL were mapped in previous studies for BW35 and BW42 between markers MCW0240 (198.7 cM) and LEI0063 $(235.2 \mathrm{cM})$ in the $\mathrm{F}_{2}$ population of Embrapa (Ambo et al., 2009; Baron et al., 2010). Furthermore, these genes were chosen because they had functions directly associated with the QTL. Figure 1 depicts the linkage map of the target region in which the QTL were mapped for BW35 and BW42 between MCW0240-LEIO063 markers and SNPs selected in the 2 candidates genes, FGFBP1 (228.8 $\mathrm{cM})$ and $F G F B P 2(228.7 \mathrm{cM})$.

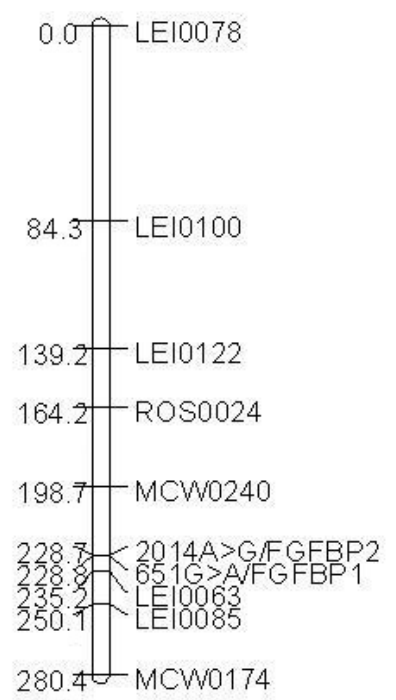

Figure 1. Representation of the target region studied in the GGA4 through the linkage map of partial binding with the respective microsatellite marker (Ambo et al., 2009; Baron et al., 2010) and the position of two SNPs identified in the FGFBP1 (g.651G $>$ A) and FGFP2 (g.2014> G) genes. The marker position is represented in centiMorgans (cM). The first maker represented is the LEI0078 positioned to $82.9 \mathrm{cM}$ in the chicken consensus map (Schmid et al., 2005). For the graphical representation of this map, the Map Chart version 2.1 program (Voorrips, 2002) was used. 


\section{Polymerase chain reaction (PCR) conditions and sequencing}

Primers were designed to amplify exon and intron regions of chicken sequences for FGFBP1 and FGFBP2 genes deposited in GenBank (accession No. NC_006091.3; 2012) using the Primer3 computer program (http://frodo.wi.mit.edu/). The quality of the primers was analyzed by the NetPrimer program (http://www.premierbiosoft.com/netprimer), and their sequences are presented in Table 1.

Gene fragments were amplified by PCR in a final volume of $25 \mu \mathrm{L}$ consisting of $20 \mathrm{ng}$ genomic DNA, $2.5 \mu \mathrm{L}$ 10X buffer ( $50 \mathrm{mM} \mathrm{KCl}, 10 \mathrm{mM}$ Tris- $\mathrm{HCl}, \mathrm{pH}$ 8.5), $0.3 \mathrm{mM} \mathrm{MgCl}, 0.4$ mM dNTP, 2 pmoL of each primer, and 1 U Platinum Taq DNA polymerase (Life Technologies). Fragment amplification was performed as follows: initial denaturation at $95^{\circ} \mathrm{C}$ for $1 \mathrm{~min}, 30$ cycles of $95^{\circ} \mathrm{C}$ for $1 \mathrm{~min}$, the specific annealing temperature for each primer pair for $1 \mathrm{~min}$, extension at $72^{\circ} \mathrm{C}$ for $1 \mathrm{~min}$, and a final extension at $72^{\circ} \mathrm{C}$ for $10 \mathrm{~min}$. The size of the amplified fragments was confirmed using the molecular weight marker $\Phi$ X174 (Life Technologies) and estimated on a 1\% agarose gel.

PCR products were purified and sequencing reactions were performed according to the Big Dye Terminator Cycle Sequencing Ready Reaction protocol (Life Technologies). Sequencing reactions were purified and applied in the automated sequencer, ABI PRISM 3100 Genetic Analyzer (Applied Biosystems, Foster City, CA, USA). Nucleotide sequences were edited, assembled, and analyzed using the Phred, Phrap, and Consed programs, respectively (Ewing and Green, 1998; Gordon et al., 1998).

\section{Genotyping of polymorphisms}

Once polymorphisms were detected in $\mathrm{F}_{1}$ animals of the Embrapa population, $1 \mathrm{SNP}$ in each gene (FGFBP1 and FGFBP2) were selected based on 2 more informative full-sib families (heterozygous genotypes) to genotype $179 \mathrm{~F}_{2}$ broilers from Embrapa and $311 \mathrm{com}-$ mercial broilers through allelic discrimination using the TaqMan detection system (Applied Biosystems) with specific probes for each allele. Reactions were performed in a LightCycler 480 System II (Roche, Mannheim, Germany), using the endpoint genotyping method. Results were analyzed using the LightCycler 480 SW 1.5 software (Roche).

\section{Statistical analysis}

Allelic and genotypic frequencies were estimated for each locus by simply counting the number of alleles and genotypes, respectively, as described by Falconer and Mackay (2001).

To assess the implications of molecular results on all of the relevant poultry traits, individual analyses were used and each feature was considered a dependent variable. Genotypic effects found for both markers ( $F G F B P 1$ and $F G F B P 2$ ) were evaluated from the general model presented below:

$$
\mathrm{Y}_{\mathrm{ijkl}}=\mu+\mathrm{C}_{\mathrm{i}}+\mathrm{S}_{\mathrm{j}}+\mathrm{M}_{\mathrm{k}}+\mathrm{e}_{\mathrm{ijk} \mathrm{l}}
$$

where $Y_{i j k l}$ is the phenotypic value observed for a given trait in poultry; $\mu$ is the constant inherent to all observations; $C_{i}$ is the fixed effect of the contemporaneous group; $S_{j}$ is the random effect of male $\mathrm{j}$, with average 0 and variance $\sigma_{s}^{2} ; M_{k}$ is the fixed effect of the genotype for each SNP marker assessed (FGFBP1 and FGFBP2), and $e_{i j k l}$ is the residual random effect associated with trait $Y_{i j k l}$, with average 0 and variance $\sigma^{2}$. 
The effects of different haplotypes and diplotypes found for the 2 markers were evaluated based on the model described above, replacing the genotype factor of marker $M k$ with $H k$ for the 4 haplotypes or with $D k$ for the diplotypes that were evaluated.

According to Falconer and Mackay (2001), estimates of the additive effect $(\alpha)$ of each polymorphism can be obtained from the difference between the means of homozygous genotypes. The deviations attributed to dominance $(\delta)$ are estimated by the difference between the means of the heterozygous genotype in relation to the means of the 2 homozygous genotypes. Estimates of additive effects and deviations attributed to dominance were assessed using the Student $t$-test $(\mathrm{P}<0.05$ was considered to be significant).

Estimates of medium effects of allele substitution for the polymorphisms evaluated in terms of genotypes, haplotypes, and diplotypes were calculated by linear regression analysis, considering the number of favorable alleles (Falconer and Mackay, 2001). All analyses were performed using PROC FREQ and PROC MIXED functions of Statistical Analysis System version 9.2 (SAS, 2004).

\section{Construction of haplotypes}

Haplotypes were constructed based on the 2 SNPs identified in 311 animals using the PHylogenetics And Sequence Evolution program (PHASE 2.0; Stephens et al., 2001). The genetic effects of the haplotypes were calculated using the mixed model as described above.

\section{RESULTS AND DISCUSSION}

\section{Experimental population of Embrapa}

\section{Identification of SNPs in the FGFBP1 and FGFBP2 genes}

The sequence of target regions of $11 \mathrm{~F}_{1}$ individuals allowed identification of 5 polymorphic sites. In the $F G F B P 1$ gene, we found 3 polymorphisms in exon 2: g. $1849 \mathrm{~T}>\mathrm{C}$ (NCBI_ss494474886), g.1999G $>$ A (NBCI_ss494474887) and g.2014G $>$ A (NCBI_ rs 15620312). SNP g.2014G $>$ A, described in the SNP database of the National Center for Biotechnology Information (NCBI), was selected for genotyping the populations. In the $F G F B P 2$ gene, polymorphisms were identified in the 656-bp region flanked by the FGFBP2 primer (Table 1). One polymorphism was found in exon 1, g.465C > T (NCBI_rs14491579), and the other was found in intron 1, g.651G $>$ A (NCBI_rs13664051). The latter was selected for genotyping. The 2 SNPs of the FGFBP2 gene are described in the NCBI SNP database. The mutations identified in FGFBP1 and FGFBP2 genes are synonymous, and there was no change in amino acids.

\begin{tabular}{|c|c|c|c|}
\hline Gene & Primer sequences $\left(5^{\prime}-3^{\prime}\right)$ & Fragment size (bp) & Annealing temperature $\left({ }^{\circ} \mathrm{C}\right)$ \\
\hline \multirow[t]{2}{*}{ FGFBPI } & F - GCTGTGAAAGGCAGAAGGAG & & \\
\hline & R - TTGCTGAGATCGGACTGTTG & 696 & 60 \\
\hline \multirow[t]{2}{*}{ FGFBP2 } & F - GGATGAAGAGATGAAAGCGAGA & & \\
\hline & R - AAACCCCCAGAAGCCACA & 656 & 58 \\
\hline
\end{tabular}




\section{Characterization of phenotypic traits}

The number of observations and estimates of means, standard deviations, coefficients of variation, as well as minimum and maximum phenotypic traits that were studied are presented in Table 2. The $\mathrm{F}_{2}$ Embrapa population resulting from crossing independently selected strains showed greater variability compared to the commercial population.

Table 2. Descriptive information of traits evaluated for SNPs g.2014G $>\mathrm{A}(F G F B P 1)$ and g.651G $>\mathrm{A}(F G F B P 2)$ in the Embrapa $\mathrm{F}_{2}$ population.

\begin{tabular}{lcrrrrr}
\hline Trait & $\mathrm{N}$ & Mean & SD & CV & Minimum & Maximum \\
\hline BW35 (g) & 178 & 824.00 & 121.97 & 14.80 & 480.00 & 1133.00 \\
BW41 (g) & 179 & 1048.46 & 167.56 & 15.98 & 407.00 & 1439.00 \\
BW42 (g) & 179 & 1011.53 & 163.74 & 16.19 & 402.00 & 1379.00 \\
Feet (g) & 178 & 41.76 & 8.03 & 19.22 & 16.00 & 61.00 \\
Drums and thighs (g) & 179 & 222.63 & 41.61 & 18.69 & 67.00 & 323.00 \\
Breast (g) & 179 & 167.11 & 32.59 & 19.50 & 55.00 & 248.00 \\
Carcass (g) & 179 & 665.61 & 118.74 & 17.84 & 234.00 & 940.00 \\
Protein (g) & 166 & 189.08 & 32.27 & 17.07 & 78.15 & 264.27 \\
Ash (g) & 166 & 27.08 & 5.09 & 18.79 & 11.06 & 40.33 \\
\hline
\end{tabular}

BW35 = body weight at 35 days; BW41 = body weight at 41 days; BW42 = body weight at 42 days; Feet $=$ feet weight; Drums and thighs = weight of drums and thighs; Breast = breast weight with skin and bones; Carcass $=$ carcass weight obtained from the sum of carcass parts; Protein $=$ crude protein; $A s h=$ ashes; $\mathrm{N}=$ number of observations; $\mathrm{SD}=$ standard deviation; $\mathrm{CV}=$ coefficients of variation.

\section{Genotypic and allelic frequencies}

Genotypic and allelic frequencies associated with polymorphisms g.2014G $>$ A $(F G F B P 1)$ and g.651G $>\mathrm{A}(F G F B P 2)$ are presented in Table 3. The AA genotype was less frequent for the SNP g.2014G $>$ A, and the GA genotype predominated over the GG genotype. For SNP g.651G $>$ A, the AA genotype was not observed, and the GG genotype frequency was higher than that of GA. Allelic frequencies observed for SNPs g.2014G >A and g.651G $>$ A showed that allele A was less frequent than allele G.

\begin{tabular}{|c|c|c|c|c|c|}
\hline \multirow{2}{*}{ Polymorphism } & \multicolumn{3}{|c|}{ Genotypic frequency } & \multicolumn{2}{|c|}{ Allelic frequency } \\
\hline & GG & GA & AA & $\mathrm{G}$ & A \\
\hline $\begin{array}{l}\text { g. } 2014 \mathrm{G}>\mathrm{A}(F G F B P 1) \\
\text { g. } 651 \mathrm{G}>\mathrm{A}(F G F B P 2)\end{array}$ & $\begin{array}{l}32.72 \\
53.66\end{array}$ & $\begin{array}{l}50.62 \\
46.34\end{array}$ & $\begin{array}{c}16.67 \\
-\end{array}$ & $\begin{array}{l}0.58 \\
0.77\end{array}$ & $\begin{array}{l}0.42 \\
0.23\end{array}$ \\
\hline
\end{tabular}

\section{Association between polymorphisms and traits}

Associations between SNPs and the traits evaluated in the population are shown in Tables 4 and 5, for the FGFBP1 and FGFBP2 genes, respectively.

Significant additive and allele substitution effects $(\mathrm{P}<0.05)$ for polymorphism g.2014G $>$ A $(F G F B P 1)$ were observed for the characteristics of protein and ash. Presence of allele A provided, on average, $8.28 \mathrm{~g}$ protein and $1.62 \mathrm{~g}$ ash in the heterozygous animals carcass and roughly $16.56 \mathrm{~g}$ protein and $3.24 \mathrm{~g}$ ash in AA homozygous animals. The other 
phenotypic characteristics showed non-significant results $(\mathrm{P}>0.05)$ for the effects that were evaluated (Table 4).

\begin{tabular}{|c|c|c|c|c|c|c|c|c|c|}
\hline \multirow[t]{2}{*}{ Trait } & \multicolumn{3}{|c|}{ Additive effect } & \multicolumn{3}{|c|}{ Deviation of additivity } & \multicolumn{3}{|c|}{ Allele substitution effect } \\
\hline & $\alpha$ & $\mathrm{SE}$ & $P>|t|$ & $\delta$ & $\mathrm{SE}$ & $P>|t|$ & $\beta_{l i}$ & $\mathrm{SE}$ & $P>|t|$ \\
\hline BW35 (g) & 35.06 & 29.39 & 0.24 & -2.40 & 16.37 & 0.88 & 16.83 & 13.99 & 0.23 \\
\hline BW41 (g) & 26.80 & 40.03 & 0.50 & 14.08 & 22.49 & 0.53 & 17.46 & 19.03 & 0.36 \\
\hline BW42 (g) & 40.69 & 37.92 & 0.29 & 13.25 & 21.89 & 0.55 & 24.33 & 17.98 & 0.18 \\
\hline Feet $(\mathrm{g})$ & 0.79 & 1.58 & 0.62 & 1.43 & 0.90 & 0.11 & 0.81 & 0.75 & 0.28 \\
\hline Drums and thighs $(\mathrm{g})$ & 6.36 & 9.62 & 0.51 & 5.01 & 5.32 & 0.35 & 4.6 & 4.58 & 0.32 \\
\hline Breast (g) & 8.12 & 8.15 & 0.32 & 2.97 & 4.56 & 0.52 & 4.91 & 3.87 & 0.21 \\
\hline Carcass (g) & 19.01 & 28.00 & 0.50 & 10.06 & 15.64 & 0.52 & 12.39 & 13.32 & 0.35 \\
\hline Protein (g) & 14.22 & 6.71 & $0.04^{\mathrm{a}}$ & 5.47 & 4.57 & 0.23 & 8.28 & 3.21 & $0.01^{\mathrm{a}}$ \\
\hline $\operatorname{Ash}(\mathrm{g})$ & 2.73 & 1.29 & $0.04^{\mathrm{a}}$ & 0.84 & 0.78 & 0.29 & 1.62 & 0.60 & $0.01^{\mathrm{a}}$ \\
\hline
\end{tabular}

${ }^{\text {ap }}<0.05$. BW35 = body weight at 35 days; BW41 = body weight at 41 days; BW42 = body weight at 42 days; Feet $=$ feet weight; Drums and thighs $=$ weight of drums and thighs; Breast $=$ breast weight with skin and bones; Carcass $=$ carcass weight obtained from the sum of carcass parts; Protein = crude protein; Ash = ashes. SE = standard error.

Table 5. Estimate of the average effect of allele substitution $\left(\beta_{l i}\right)$ for phenotypic traits of SNP g.651G $>$ A $(F G F B P 2)$ in the Embrapa $\mathrm{F}_{2}$ population.

\begin{tabular}{lrcc}
\hline Trait & \multicolumn{3}{c}{ Allele substitution effect } \\
\cline { 2 - 4 } & $\beta_{l i}$ & $\mathrm{SE}$ & $\mathrm{P}>|\mathrm{t}|$ \\
\hline BW35 (g) & 35.52 & 14.65 & $0.02^{\mathrm{a}}$ \\
BW41 (g) & 54.75 & 21.11 & $0.01^{\mathrm{a}}$ \\
BW42 (g) & 57.40 & 20.41 & $0.01^{\mathrm{a}}$ \\
Feet (g) & 3.73 & 0.86 & $0.0001^{\mathrm{c}}$ \\
Drums and thighs (g) & 15.09 & 4.86 & $0.002^{\mathrm{a}}$ \\
Breast (g) & 12.26 & 4.09 & $0.003^{\mathrm{a}}$ \\
Carcass (g) & 38.49 & 14.32 & $0.01^{\mathrm{a}}$ \\
Protein (g) & 12.58 & 4.23 & $0.004^{\mathrm{a}}$ \\
Ash (g) & 2.56 & 0.70 & $0.0004^{\mathrm{b}}$ \\
\hline
\end{tabular}

${ }^{\mathrm{a}} \mathrm{P}<0.05,{ }^{\mathrm{b}} \mathrm{P}<0.001,{ }^{\mathrm{c}} \mathrm{P}<0.0001 . \mathrm{BW} 35$ = body weight at 35 days; BW41 = body weight at 41 days; BW42 = body weight at 42 days; Feet = feet weight; Drums and thighs = drumstick and thigh weight; Breast = breast weight with skin and bones; Carcass $=$ carcass weight obtained from the sum of carcass parts; Protein $=$ crude protein; Ash $=$ ash; $\mathrm{SE}=\mathrm{standard}$ error.

For the SNP g.651G $>$ A (FGFBP2; Table 5), since AA genotype animals were not observed, we estimated allele substitution effects only among GG and GA animals. Significant effects $(\mathrm{P}<0.05)$ were observed for all of the traits described in Table 5. Chickens with the GA genotype had higher body and cut weight at different ages compared to birds with the GG genotype. These results are not surprising, as this is the same population in which the QTL for these traits were identified with microsatellite markers.

\section{Commercial population}

Observations, estimated means, standard deviations, coefficients of variation as well as minimum and maximum phenotypic traits for the commercial population are shown in Table 6.

Genotypic and allelic frequencies obtained for the 2 polymorphisms evaluated in the commercial population, g.2014G $>\mathrm{A}(F G F B P 1)$ and g.651G $>\mathrm{A}(F G F B P 2)$, are presented in Table 7. The GA genotype was more frequent for SNP g.2014G $>$ A of the FGFBP1 gene, and the GG genotype was more common for SNP g.651G $>$ A of the $F G F B P 2$ gene. 
Table 6. Descriptive information of the traits evaluated in the commercial population.

\begin{tabular}{|c|c|c|c|c|c|c|}
\hline Trait & $\mathrm{N}$ & Mean & SD & $\mathrm{CV}$ & Minimum & Maximum \\
\hline SW (g) & 310 & 1528.90 & 160.00 & 10.46 & 970.00 & 1980.00 \\
\hline SBW (g) & 310 & 3101.37 & 278.09 & 8.97 & 1231.00 & 3753.00 \\
\hline EBW (g) & 310 & 2214.41 & 196.59 & 8.88 & 1318.00 & 2762.00 \\
\hline BRT (g) & 310 & 641.76 & 81.71 & 12.73 & 356.00 & 892.00 \\
\hline LW (g) & 310 & 757.13 & 75.81 & 10.01 & 358.00 & 918.00 \\
\hline $\mathrm{pHf}$ & 311 & 6.18 & 0.20 & 3.31 & 5.44 & 6.83 \\
\hline DL (\%) & 310 & 2.20 & 0.75 & 34.35 & 0.96 & 6.27 \\
\hline TL $(\%)$ & 310 & 3.92 & 2.75 & 70.16 & 0.28 & 28.36 \\
\hline TCL $(\%)$ & 311 & 14.13 & 4.01 & 28.41 & 4.63 & 25.16 \\
\hline TWL (\%) & 311 & 20.19 & 5.68 & 28.10 & 8.63 & 56.18 \\
\hline $\mathrm{L}^{*}$ & 308 & 54.98 & 3.29 & 5.98 & 44.61 & 63.90 \\
\hline$a^{*}$ & 308 & 5.94 & 1.24 & 20.92 & 3.42 & 10.42 \\
\hline $\mathrm{b}^{*}$ & 308 & 14.41 & 1.57 & 10.92 & 10.35 & 20.16 \\
\hline $\operatorname{MFD}(\mu \mathrm{m})$ & 311 & 46.50 & 6.95 & 14.95 & 31.11 & 67.92 \\
\hline SF (kgf) & 311 & 1.59 & 0.51 & 31.98 & 0.50 & 4.00 \\
\hline
\end{tabular}

$\mathrm{SW}=$ selection body weight at 38 days; $\mathrm{SBW}=$ slaughter body weight $\mathrm{EBW}=$ eviscerated carcass weight; $\mathrm{BRT}=$ breast weight; $\mathrm{LW}=$ leg weight; $\mathrm{pHf}=\mathrm{pH} 24 \mathrm{~h}$ after slaughter; $\mathrm{DL}=$ drip loss; $\mathrm{TL}=$ thawing loss; $\mathrm{TCL}=$ thawing-cooking loss; $\mathrm{TML}=$ total water loss; $\mathrm{L}^{*}=$ lightness content; $\mathrm{a}^{*}=$ redness content; $\mathrm{b}^{*}=$ yellowness content; $\mathrm{MFD}=$ muscle fiber diameter; $\mathrm{SF}=$ shear force; $\mathrm{N}=$ number of observations; $\mathrm{SD}=$ standard deviation; $\mathrm{CV}=$ coefficients of variation.

Table 7. Genotypic and allelic frequencies for polymorphisms g.2014G $>$ A $(F G F B P 1)$ and g.651G $>$ A $(F G F B P 2)$ in the commercial population.

\begin{tabular}{lccrcc}
\hline Polymorphism & \multicolumn{3}{c}{ Genotypic frequency } & & \multicolumn{2}{c}{ Allelic frequency } \\
\cline { 2 - 6 } & GG & GA & AA & G & 0.55 \\
\hline g.2014G $>$ A $(F G F B P I)$ & 30.65 & 48.39 & 20.96 & 0.45 \\
g.651G $>$ A $(F G F B P 2)$ & 92.6 & 6.11 & 1.29 & 0.96 & 0.04 \\
\hline
\end{tabular}

Regarding SNP g.2014G $>$ A, the frequency of allele G was slightly higher compared to that of allele A. Allelic frequencies observed for SNP g.651G $>$ A showed that allele $\mathrm{G}$ is practically fixed in this commercial population. Interestingly, this was not the same allele associated with performance traits in the experimental population.

\section{Association between polymorphisms and traits}

Estimates of an additive effect, additive deviation and allele substitution effect for polymorphism g.2014G $>$ A in the FGFBP1 gene are shown in Table 8.

The EBW trait showed a significant additive effect and allele substitution effect for the SNP g.2014G $>$ A ( $F G F B P 1)$. Chickens with the AA genotype had, on average, $70 \mathrm{~g}$ more EBW relative to the GA and GG genotypes, with no adverse effect on meat quality. Considering the frequency of this allele in the commercial population, there is potential to increase EBW with no adverse effect on meat quality traits.

In SNP g.651G $>$ A $(F G F B P 2)$, the estimated effects of additivity, dominance, and allele substitution were significant $(\mathrm{P}<0.0001)$ for drip loss (Table 9). The estimated average allele substitution effect was $0.5 \%$ more water in the breast muscle. In this case, the unfavorable allele has a lower frequency in the commercial population; consequently, the impact of this marker on a breeding program for this population would be small. 


\begin{tabular}{|c|c|c|c|c|c|c|c|c|c|}
\hline \multirow[t]{2}{*}{ Trait } & \multicolumn{3}{|c|}{ Additive effect } & \multicolumn{3}{|c|}{ Deviation of additivity } & \multicolumn{3}{|c|}{ Allele substitution effect } \\
\hline & $\alpha$ & SE & $P>|t|$ & $\delta$ & $\mathrm{SE}$ & $P>|t|$ & $\beta_{l i}$ & SE & $\mathrm{P}>|\mathrm{t}|$ \\
\hline$\overline{\mathrm{SW}(\mathrm{g})}$ & 32.26 & 25.75 & 0.21 & 19.14 & 17.47 & 0.27 & 18.12 & 12.76 & 0.16 \\
\hline SBW (g) & 33.06 & 43.61 & 0.45 & 10.83 & 30.53 & 0.72 & 17.66 & 21.54 & 0.41 \\
\hline EBW (g) & 69.33 & 31.34 & $0.03^{\mathrm{a}}$ & 4.99 & 21.26 & 0.81 & 35.15 & 15.51 & $0.02^{\mathrm{a}}$ \\
\hline BRT (g) & 19.82 & 11.90 & 0.10 & 3.42 & 7.93 & 0.67 & 10.23 & 5.90 & 0.08 \\
\hline LW (g) & 22.50 & 12.65 & 0.08 & 1.20 & 8.64 & 0.89 & 11.37 & 6.26 & 0.07 \\
\hline $\mathrm{pHf}$ & -0.06 & 0.03 & 0.07 & -0.01 & 0.02 & 0.71 & -0.03 & 0.02 & 0.06 \\
\hline DL (\%) & 0.15 & 0.13 & 0.23 & -0.03 & 0.09 & 0.73 & 0.07 & 0.06 & 0.25 \\
\hline TL (\%) & 0.05 & 0.43 & 0.92 & 0.33 & 0.29 & 0.26 & 0.05 & 0.21 & 0.81 \\
\hline TCL $(\%)$ & 0.44 & 0.53 & 0.40 & -0.27 & 0.36 & 0.46 & 0.20 & 0.26 & 0.45 \\
\hline TWL (\%) & 0.61 & 0.78 & 0.44 & 0.12 & 0.53 & 0.81 & 0.32 & 0.39 & 0.42 \\
\hline $\mathrm{L}^{*}$ & -0.25 & 0.45 & 0.59 & -0.31 & 0.31 & 0.31 & -0.15 & 0.23 & 0.50 \\
\hline$a^{*}$ & 0.29 & 0.17 & 0.09 & 0.09 & 0.12 & 0.45 & 0.15 & 0.08 & 0.07 \\
\hline $\mathrm{b}^{*}$ & 0.08 & 0.22 & 0.71 & 0.07 & 0.16 & 0.63 & 0.05 & 0.11 & 0.66 \\
\hline $\operatorname{MFD}(\mu \mathrm{m})$ & -0.47 & 0.88 & 0.59 & 0.50 & 0.59 & 0.40 & -0.19 & 0.43 & 0.66 \\
\hline SF (kgf) & 0.13 & 0.07 & 0.07 & -0.03 & 0.05 & 0.52 & 0.06 & 0.03 & 0.08 \\
\hline
\end{tabular}

${ }^{\mathrm{a}}<0.05 . \mathrm{SW}=$ selection body weight at 38 days; SBW $=$ slaughter body weight; EBW = eviscerated carcass weight; $\mathrm{BRT}=$ breast weight; $\mathrm{LW}=$ leg weight; $\mathrm{pHf}=\mathrm{pH} 24 \mathrm{~h}$ after slaughter; $\mathrm{DL}=$ drip loss; $\mathrm{TL}=$ thawing loss; $\mathrm{TCL}=$ thawing-cooking loss; $\mathrm{TML}=$ total water loss; $\mathrm{L}^{*}=$ lightness content; $\mathrm{a}^{*}=$ redness content; $\mathrm{b}^{*}=$ yellowness content; MFD = muscle fiber diameter; $\mathrm{SF}=$ shear force.

Table 9. Estimates of the additive effect $(\alpha)$, deviation of additivity $(\delta)$ and average effect of allele substitution $\left(\beta_{l i}\right)$ for phenotypic traits of SNP g.651G $>\mathrm{A}(F G F B P 2)$ in the commercial population.

\begin{tabular}{|c|c|c|c|c|c|c|c|c|c|}
\hline \multirow[t]{2}{*}{ Trait } & \multicolumn{3}{|c|}{ Additive effect } & \multicolumn{3}{|c|}{ Deviation of additivity } & \multicolumn{3}{|c|}{ Allele substitution effect } \\
\hline & $\alpha$ & $\mathrm{SE}$ & $P>|t|$ & $\delta$ & SE & $P>|t|$ & $\beta_{l i}$ & SE & $P>|t|$ \\
\hline SW (g) & 106.80 & 80.88 & 0.19 & -31.49 & 52.57 & 0.55 & 35.99 & 28.11 & 0.20 \\
\hline SBW (g) & 29.85 & 136.49 & 0.83 & 45.20 & 92.23 & 0.62 & 38.63 & 48.33 & 0.42 \\
\hline EBW (g) & -61.63 & 98.83 & 0.53 & 44.84 & 64.84 & 0.49 & -6.47 & 34.76 & 0.85 \\
\hline BRT $(g)$ & -8.58 & 37.34 & 0.82 & 3.15 & 24.20 & 0.90 & -2.56 & 13.08 & 0.85 \\
\hline LW (g) & -32.68 & 39.82 & 0.41 & 9.19 & 26.26 & 0.73 & -11.36 & 14.01 & 0.42 \\
\hline $\mathrm{pHf}$ & -0.01 & 0.10 & 0.94 & -0.03 & 0.07 & 0.63 & -0.02 & 0.04 & 0.55 \\
\hline DL (\%) & 1.57 & 0.38 & $0.0001^{\mathrm{c}}$ & -0.53 & 0.25 & $0.03^{\mathrm{a}}$ & 0.49 & 0.13 & $0.0003^{\mathrm{b}}$ \\
\hline TL (\%) & -0.29 & 1.36 & 0.83 & -0.15 & 0.88 & 0.87 & -0.23 & 0.47 & 0.63 \\
\hline TCL $(\%)$ & 0.01 & 1.65 & 1.00 & 1.18 & 1.09 & 0.28 & 0.64 & 0.58 & 0.27 \\
\hline TWL (\%) & 1.10 & 2.45 & 0.66 & 0.60 & 1.60 & 0.71 & 0.88 & 0.85 & 0.30 \\
\hline $\mathrm{L}^{*}$ & 0.28 & 1.42 & 0.85 & 0.82 & 0.92 & 0.37 & 0.59 & 0.49 & 0.23 \\
\hline$a^{*}$ & 1.22 & 0.53 & $0.02^{\mathrm{a}}$ & -0.59 & 0.35 & 0.09 & 0.29 & 0.18 & 0.12 \\
\hline$b^{*}$ & 0.21 & 0.70 & 0.76 & 0.41 & 0.46 & 0.37 & 0.33 & 0.24 & 0.18 \\
\hline $\operatorname{MFD}(\mu \mathrm{m})$ & 0.69 & 2.75 & 0.80 & -0.54 & 1.79 & 0.76 & 0.05 & 0.96 & 0.96 \\
\hline $\mathrm{SF}(\mathrm{kgf})$ & 0.03 & 0.22 & 0.89 & -0.06 & 0.15 & 0.69 & -0.02 & 0.08 & 0.83 \\
\hline
\end{tabular}

${ }^{\mathrm{a} P}<0.05,{ }^{\mathrm{b}} \mathrm{P}<0.001,{ }^{\mathrm{c}} \mathrm{P}<0.0001$. SW $=$ selection body weight at 38 days; SBW = slaughter body weight; EBW $=$ eviscerated carcass weight; $\mathrm{BRT}=$ breast weight; $\mathrm{LW}=$ leg weight; $\mathrm{pHf}=\mathrm{pH} 24 \mathrm{~h}$ after slaughter; $\mathrm{DL}=$ drip loss; $\mathrm{TL}=$ thawing loss; $\mathrm{TCL}=$ thawing-cooking loss; $\mathrm{TML}=$ total water loss; $\mathrm{L}^{*}=$ lightness content; $\mathrm{a}^{*}=$ redness content; $\mathrm{b}^{*}=$ yellowness content; $\mathrm{MFD}=$ muscle fiber diameter; $\mathrm{SF}=$ shear force; $\mathrm{SE}=$ standard error.

Values of a* showed a significant additive effect for SNP g.651G $>$ A. For the other phenotypic traits, no significant results were observed $(\mathrm{P}>0.05)$ for the evaluated effects.

\section{Construction of haplotypes and diplotypes and their frequencies}

Four haplotypes were constructed based on the 2 SNPs identified in this study for the 
311 animals of the commercial population using the PHASE program (Table 10). Six diplotypes were obtained based on the haplotypes found in the commercial population (Table 11).

\begin{tabular}{|c|c|c|c|}
\hline Haplotype & g. $2014 \mathrm{G}>\mathrm{A}$ & g. $651 \mathrm{G}>\mathrm{A}$ & Frequency (\%) \\
\hline $\mathrm{H} 1$ & G & G & 52.74 \\
\hline $\mathrm{H} 2$ & G & A & 2.10 \\
\hline $\mathrm{H} 3$ & A & G & 42.90 \\
\hline $\mathrm{H} 4$ & A & A & 2.26 \\
\hline
\end{tabular}

Table 11. Diplotype frequencies for polymorphisms g.2014G $>$ A $(F G F B P 1)$ and g.651G $>$ A $(F G F B P 2)$ in the commercial population.

\begin{tabular}{lc}
\hline Diplotype & Frequency $(\%)$ \\
\hline H1H1 & 30.32 \\
H3H1 & 44.84 \\
H3H2 & 3.55 \\
H3H3 & 17.42 \\
H3H4 & 2.58 \\
H4H4 & 0.97 \\
\hline
\end{tabular}

\section{Associations of haplotypes and diplotypes with traits of economic interest}

In the haplotype analyses, significant results $(\mathrm{P}<0.05)$ were found for BRT, EBW $(\%)$ and $\mathrm{a}^{*}$ values (Table 12). For the other traits, no significant results were observed $(\mathrm{P}>0.05)$. In analyses considering the effects of diplotypes formed from haplotypes, significant results ( $\mathrm{P}$ $<0.05)$ were detected for EBW and $\mathrm{a}^{*}$ values. Other traits were not significant $(\mathrm{P}>0.05)$ for the variation source of diplotypes (Table 12).

Table 12. Summary of association analyses considering haplotypes and diplotypes for polymorphisms g.2014G $>\mathrm{A}(F G F B P 1)$ and g.651G $>\mathrm{A}(F G F B P 2)$ in the commercial population.

\begin{tabular}{|c|c|c|c|c|c|c|c|c|}
\hline \multirow[t]{2}{*}{ Trait } & \multicolumn{4}{|c|}{ Haplotypes } & \multicolumn{4}{|c|}{ Diplotypes } \\
\hline & d.f.n. & d.f.d. & F value & $\mathrm{P}>\mathrm{F}$ & d.f.n. & d.f.d. & F value & $\mathrm{P}>\mathrm{F}$ \\
\hline SW (g) & 3 & 268 & 1.08 & 0.3553 & 5 & 264 & 0.94 & 0.4540 \\
\hline SBW (g) & 3 & 268 & 1.50 & 0.2142 & 5 & 264 & 0.74 & 0.5961 \\
\hline EBW (g) & 3 & 268 & 2.56 & 0.0539 & 5 & 264 & 1.10 & 0.3614 \\
\hline $\operatorname{BRT}(\mathrm{g})$ & 3 & 268 & 3.22 & $0.0226^{\mathrm{a}}$ & 5 & 264 & 0.89 & 0.4915 \\
\hline LW (g) & 3 & 268 & 1.74 & 0.1576 & 5 & 264 & 0.79 & 0.5543 \\
\hline $\mathrm{pHf}$ & 3 & 269 & 1.39 & 0.2444 & 5 & 265 & 1.11 & 0.3566 \\
\hline DL (\%) & 3 & 268 & 4.68 & $0.0031^{\mathrm{a}}$ & 5 & 264 & 7.69 & $<.0001^{\mathrm{b}}$ \\
\hline TL $(\%)$ & 3 & 268 & 0.33 & 0.8048 & 5 & 264 & 0.34 & 0.8885 \\
\hline TCL (\%) & 3 & 269 & 1.68 & 0.1697 & 5 & 265 & 1.21 & 0.3023 \\
\hline TWL (\%) & 3 & 269 & 1.04 & 0.3755 & 5 & 265 & 1.06 & 0.3842 \\
\hline $\mathrm{L}^{*}$ & 3 & 266 & 0.53 & 0.6642 & 5 & 262 & 2.16 & 0.0590 \\
\hline$a^{*}$ & 3 & 266 & 4.02 & $0.0076^{a}$ & 5 & 262 & 2.51 & $0.0305^{\mathrm{a}}$ \\
\hline $\mathrm{b}^{*}$ & 3 & 266 & 1.05 & 0.3699 & 5 & 262 & 0.96 & 0.4399 \\
\hline $\operatorname{MFD}(\mu \mathrm{m})$ & 3 & 269 & 0.22 & 0.8837 & 5 & 265 & 0.63 & 0.6773 \\
\hline $\mathrm{SF}$ (kgf) & 3 & 269 & 0.19 & 0.9022 & 5 & 265 & 0.54 & 0.7487 \\
\hline $\mathrm{SW}(\mathrm{g})$ & 3 & 269 & 0.22 & 0.8792 & 5 & 265 & 0.31 & 0.9086 \\
\hline SBW (g) & 3 & 269 & 1.77 & 0.1518 & 5 & 265 & 1.66 & 0.1449 \\
\hline
\end{tabular}

${ }^{\mathrm{a}} \mathrm{P}<0.05$, ${ }^{\mathrm{b}} \mathrm{P}<0.001$. d.f.n. and d.f.d. = numerator and denominator degrees of freedom, respectively. $\mathrm{SW}=$ selection body weight at 38 days; SBW = slaughter body weight; $\mathrm{EBW}=$ eviscerated carcass weight; $\mathrm{BRT}=$ breast weight; $\mathrm{LW}=$ leg weight; $\mathrm{pHf}=\mathrm{pH} 24 \mathrm{~h}$ after slaughter; $\mathrm{DL}=$ drip loss; $\mathrm{TL}=$ thawing loss; $\mathrm{TCL}=$ thawing-cooking loss; $\mathrm{TML}=$ total water loss; $\mathrm{L}^{*}=$ lightness content; $\mathrm{a}^{*}=$ redness content; $\mathrm{b}^{*}=$ yellowness content; $\mathrm{MFD}=$ muscle fiber diameter; $\mathrm{SF}=$ shear force. 
The estimates of means and standard errors for the traits evaluated according to the 4 haplotypes are presented in Table 13. Haplotypes H1, H3, and H4 had the highest BRT averages. For EBW, H2, and H4 haplotypes had greater TCL. For a* values, animals with haplotype $\mathrm{H} 4$ had significantly higher redness content in the meat $(\mathrm{P}<0.01)$ compared to animals with other haplotypes.

Table 13. Estimates of means and standard errors in association analyses considering the haplotypes observed for polymorphisms g.2014G $>\mathrm{A}(F G F B P 1)$ and g.651G $>\mathrm{A}(F G F B P 2)$ in the commercial population.

\begin{tabular}{|c|c|c|c|c|c|c|c|c|}
\hline \multirow[t]{2}{*}{ Trait } & \multicolumn{2}{|c|}{ H1 (GG) } & \multicolumn{2}{|c|}{ H2 (GA) } & \multicolumn{2}{|c|}{ H3 (AG) } & \multicolumn{2}{|c|}{$\mathrm{H} 4$ (AA) } \\
\hline & Mean & SE & Mean & $\mathrm{SE}$ & Mean & SE & Mean & SE \\
\hline SW (g) & 1521.64 & 13.14 & 1553.56 & 42.47 & 1531.18 & 13.59 & 1588.49 & 41.51 \\
\hline SBW (g) & 3088.56 & 19.24 & 3020.10 & 73.99 & 3088.10 & 20.16 & 3225.21 & 74.60 \\
\hline EBW (g) & 2193.50 & 15.63 & 2102.53 & 51.73 & 2214.56 & 16.18 & 2264.40 & 52.20 \\
\hline BRT (g) & 634.80 & $6.73^{\mathrm{AB}}$ & 591.01 & $19.38^{\mathrm{B}}$ & 639.07 & $6.91^{\mathrm{AB}}$ & 666.03 & $19.56^{\mathrm{A}}$ \\
\hline LW (g) & 752.01 & 6.13 & 715.07 & 20.99 & 758.96 & 6.36 & 761.34 & 21.18 \\
\hline pHf & 6.19 & 0.02 & 6.23 & 0.05 & 6.17 & 0.02 & 6.10 & 0.05 \\
\hline DL (\%) & 2.15 & $0.06^{\mathrm{B}}$ & 2.55 & $0.21^{\mathrm{AB}}$ & 2.20 & $0.06^{\mathrm{B}}$ & 2.81 & $0.20^{\mathrm{A}}$ \\
\hline TL (\%) & 4.02 & 0.22 & 3.64 & 0.72 & 4.14 & 0.23 & 3.65 & 0.70 \\
\hline TCL (\%) & 14.27 & 0.25 & 16.01 & 0.89 & 14.62 & 0.26 & 14.41 & 0.86 \\
\hline TWL (\%) & 20.40 & 0.41 & 22.15 & 1.29 & 20.90 & 0.42 & 20.79 & 1.26 \\
\hline $\mathrm{L}^{*}$ & 55.61 & 0.24 & 56.43 & 0.75 & 55.52 & 0.24 & 55.72 & 0.73 \\
\hline$a^{*}$ & 5.74 & $0.08^{\mathrm{B}}$ & 5.55 & $0.28^{\mathrm{B}}$ & 5.81 & $0.09^{\mathrm{B}}$ & 6.62 & $0.27^{\mathrm{A}}$ \\
\hline$b^{*}$ & 14.42 & 0.11 & 14.40 & 0.37 & 14.43 & 0.11 & 15.06 & 0.37 \\
\hline $\operatorname{MFA}\left(\mu \mathrm{m}^{2}\right)$ & 1818.01 & 35.15 & 1777.22 & 113.26 & 1797.11 & 36.29 & 1854.12 & 110.70 \\
\hline $\operatorname{MFD}(\mu \mathrm{m})$ & 46.83 & 0.46 & 46.26 & 1.45 & 46.56 & 0.47 & 47.09 & 1.41 \\
\hline MFN & 9.29 & 0.22 & 9.15 & 0.65 & 9.34 & 0.22 & 9.76 & 0.63 \\
\hline SF (kgf) & 1.57 & 0.03 & 1.65 & 0.12 & 1.64 & 0.03 & 1.52 & 0.12 \\
\hline
\end{tabular}

Means followed by the same superscript letters in a row do not differ according to the Student $t$-test. SW $=$ selection body weight at 38 days; SBW = slaughter body weight; EBW = eviscerated carcass weight; BRT = breast weight; $\mathrm{LW}=$ leg weight; $\mathrm{pHf}=\mathrm{pH} 24 \mathrm{~h}$ after slaughter; $\mathrm{DL}=$ drip loss; $\mathrm{TL}=$ thawing loss; $\mathrm{TCL}=$ thawing-cooking loss; $\mathrm{TML}=$ total water loss; $\mathrm{L}^{*}=$ lightness content; $\mathrm{a}^{*}=$ redness content; $\mathrm{b}^{*}=$ yellowness content; MFA = muscle fiber area; $\mathrm{MFD}=$ muscle fiber diameter; $\mathrm{MFN}=$ muscle fiber number; $\mathrm{SF}=$ shear force; $\mathrm{SE}=$ standard error.

Estimates of means and standard errors for the traits evaluated according to diplotype are shown in Table 14. Chickens with diplotypes H4H4 (AAAA), H3H2 (AGGA), and H3H3 (AGAG) showed significantly higher TCL compared to diplotypes H1H1 (GGGG), H3H1 (AGGG), and H3H4 (AGAA). Diplotype H3H2 showed the highest average of lightness content $\left(\mathrm{L}^{*}\right)$. On the other hand, poultry with diplotype H4H4 had the highest redness content ( $\left.\mathrm{a}^{*}\right)$ in the meat compared to other diplotypes.

Meat color is influenced by decreases in $\mathrm{pH}$ during the $24 \mathrm{~h}$ after slaughter. The faster the $\mathrm{pH}$ decreases, the more intense the red color. Color intensity is associated with rapid glycolysis after animal death due to increased blood flow followed by myoglobin content retention (Le Bihan-Duval et al., 2003). According to Berri et al. (2007), chicken $\mathrm{pH}$ values at 24 $\mathrm{h}$ must be between 5.7 and 5.9. Values of 6.0 or more result in greater fluid retention (ability to retain water) and more intense redness. Results of the present study were similar to those found by Berri et al. (2007). On the other hand, redness content was different for TCL; these values were higher in our study. Higher TCL is desirable for both the poultry industry and the end consumer. This loss causes, in addition to problems related to the yield and quality of processed meat, effects on sensory characteristics such as juiciness, palatability, appearance, and texture (Barbut, 1997). 
Table 14. Estimates of means and standard errors in association analyses considering the diplotypes observed for polymorphisms g.2014G $>\mathrm{A}(F G F B P 1)$ and g.651G $>\mathrm{A}(F G F B P 2)$ in the commercial population.

\begin{tabular}{|c|c|c|c|c|c|c|c|c|c|c|c|c|}
\hline \multirow[t]{2}{*}{ Trait } & \multicolumn{2}{|c|}{ H1H1 (GGGG) } & \multicolumn{2}{|c|}{ H3H1 (AGGG) } & \multicolumn{2}{|c|}{ H3H2 (AGGA) } & \multicolumn{2}{|c|}{ H3H3 (AGAG) } & \multicolumn{2}{|c|}{ H3H4 (AGAA) } & \multicolumn{2}{|c|}{ H4H4 (AAAA) } \\
\hline & Mean & SE & Mean & SE & Mean & SE & Mean & $\mathrm{SE}$ & Mean & SE & Mean & $\mathrm{SE}$ \\
\hline$\overline{\mathrm{SW}(\mathrm{g})}$ & 1503.31 & 18.50 & 1539.58 & 15.60 & 1542.31 & 47.37 & 1526.79 & 23.07 & 1557.13 & 55.67 & 1627.63 & 90.62 \\
\hline SBW (g) & 3075.97 & 29.51 & 3099.23 & 24.60 & 3093.07 & 81.86 & 3076.76 & 37.42 & 3239.41 & 101.90 & 3247.21 & 155.18 \\
\hline EBW (g) & 2177.77 & 22.25 & 2205.94 & 18.83 & 2228.43 & 56.18 & 2234.90 & 27.33 & 2190.00 & 69.70 & 2359.11 & 107.53 \\
\hline BRT (g) & 629.37 & 9.02 & 639.27 & 7.79 & 633.46 & 21.25 & 642.65 & 10.83 & 634.48 & 26.25 & 704.71 & 40.64 \\
\hline LW (g) & 746.48 & 8.87 & 756.00 & 7.47 & 755.43 & 23.00 & 768.27 & 11.00 & 734.93 & 28.57 & 794.31 & 43.96 \\
\hline $\mathrm{pHf}$ & 6.21 & 0.02 & 6.18 & 0.02 & 6.12 & 0.06 & 6.16 & 0.03 & 6.18 & 0.07 & 6.00 & 0.11 \\
\hline DL (\%) & 2.15 & $0.08^{\mathrm{C}}$ & 2.13 & $0.07^{\mathrm{C}}$ & 2.84 & $0.22^{\mathrm{B}}$ & 2.24 & $0.10^{\mathrm{BC}}$ & 1.82 & $0.26^{\mathrm{C}}$ & 4.32 & $0.42^{\mathrm{A}}$ \\
\hline TL $(\%)$ & 3.88 & 0.31 & 4.24 & 0.26 & 4.06 & 0.80 & 3.99 & 0.39 & 3.37 & 0.94 & 4.20 & 1.53 \\
\hline TCL (\%) & 14.38 & 0.37 & 14.18 & 0.31 & 16.35 & 0.98 & 14.91 & 0.46 & 14.39 & 1.15 & 14.61 & 1.87 \\
\hline TWL (\%) & 20.33 & 0.57 & 20.56 & 0.48 & 23.26 & 1.44 & 21.03 & 0.70 & 19.48 & 1.69 & 22.94 & 2.76 \\
\hline $\mathrm{L}^{*}$ & 55.90 & $0.33^{\mathrm{AB}}$ & 55.25 & $0.29^{\mathrm{B}}$ & 57.59 & $0.83^{\mathrm{A}}$ & 55.61 & $0.40^{\mathrm{AB}}$ & 55.01 & $0.97^{\mathrm{AB}}$ & 57.03 & $1.58^{\mathrm{AB}}$ \\
\hline$a^{*}$ & 5.62 & $0.12^{\mathrm{B}}$ & 5.87 & $0.10^{\mathrm{AB}}$ & 5.53 & $0.31^{\mathrm{B}}$ & 5.77 & $0.15^{\mathrm{AB}}$ & 6.18 & $0.36^{\mathrm{AB}}$ & 7.31 & $0.59^{\mathrm{A}}$ \\
\hline$b^{*}$ & 14.40 & 0.16 & 14.44 & 0.14 & 15.06 & 0.41 & 14.34 & 0.19 & 14.76 & 0.49 & 15.52 & 0.79 \\
\hline $\operatorname{MFA}\left(\mu \mathrm{m}^{2}\right)$ & 1812.59 & 50.13 & 1831.67 & 42.47 & 1876.87 & 126.12 & 1756.37 & 61.50 & 1707.96 & 148.27 & 2072.16 & 241.43 \\
\hline $\operatorname{MFD}(\mu \mathrm{m})$ & 46.78 & 0.65 & 46.94 & 0.55 & 47.46 & 1.61 & 46.17 & 0.79 & 45.20 & 1.90 & 49.83 & 3.09 \\
\hline MFN & 9.28 & 0.30 & 9.32 & 0.25 & 9.26 & 0.73 & 9.25 & 0.36 & 10.31 & 0.85 & 9.06 & 1.39 \\
\hline SF (kgf) & 1.55 & 0.05 & 1.58 & 0.04 & 1.66 & 0.13 & 1.73 & 0.06 & 1.39 & 0.15 & 1.65 & 0.25 \\
\hline
\end{tabular}

Means followed by the same superscript letters in a row do not differ according to the Student $t$-test. SW $=$ selection body weight at 38 days; SBW = slaughter body weight; EBW = eviscerated carcass weight; BRT = breast weight; $\mathrm{LW}=$ leg weight; $\mathrm{pHf}=\mathrm{pH} 24 \mathrm{~h}$ after slaughter; $\mathrm{DL}=$ drip loss; $\mathrm{TL}=$ thawing loss; $\mathrm{TCL}=$ thawing-cooking loss; $\mathrm{TML}=$ total water loss; $\mathrm{L}^{*}=$ lightness content; $\mathrm{a}^{*}=$ redness content; $\mathrm{b}^{*}=$ yellowness content; MFA = muscle fiber area; $\mathrm{MFD}=$ muscle fiber diameter; $\mathrm{MFN}=$ muscle fiber number; $\mathrm{SF}=$ shear force; $\mathrm{SE}=$ standard error.

FGFs are important for skeletal muscle development, which induce myoblast proliferation and differentiation of myocytes. The proteins encoded by the FGFBP1 and FGFBP2 genes induce transcription of FGFs and are called activators. These proteins recognize DNA promoting regions and influence the simultaneous transcription of several other genes (Kastner et al., 2000).

In chickens, we identified several polymorphisms in the FGFBP1 and FGFBP2 genes, although there are no studies regarding the identification and association of polymorphisms in these genes with traits of economic interest in poultry. Previous studies have shown that these genes make important contributions during stages of embryogenesis, cell differentiation, and proliferation in chickens (Marie et al., 2002; Gibby et al., 2009).

Ankra-Badu et al. (2010), studying an $\mathrm{F}_{2}$ chicken population, identified QTL for body weight, leg length (LL), and leg diameter (LD) in GGA2, 4, and 26. Mapped QTL for body weight at 5-9 weeks of age, LL and LD, are located on chromosome 4 between markers MCW0240-LEI0073 (198-220 cM) and are associated with muscle development and bone growth. The positional candidate $F G F B P 1$ and $F G F B 2$ genes are located in this GGA4 region. In a more recent study, Nassar et al. (2012) identified a QTL in the GGA4 region between 151.5 and $160.5 \mathrm{cM}$ in an $\mathrm{F}_{2}$ population of chickens (New Hampshire $\mathrm{x}$ White Leghorn) that was associated with body weight, carcass weight, breast weight, leg weight, and wing weight. These authors also reported that FGFBP1 and FGFBP2 genes in this region could influence carcass quality and muscle development.

The present study identified SNPs in $F G F B P 1$ and $F G F B P 2$ genes located in a QTL region for BW35 and BW41 between markers MCW0240-LEI0063 associated with traits of growth and muscle development (BRT, TCL, $\mathrm{L}^{*}$, and $\mathrm{a}^{*}$ ), which corroborates the findings of 
Ankra-Badu et al. (2010) and Nassar et al. (2012). These traits are of paramount importance to the poultry industry, since selection for rapid poultry growth is related to meat quality.

The significant results observed in the different populations showed that polymorphisms identified in FGFBP1 and FGFBP2 genes located in QTL regions can represent possible candidate genes in poultry breeding programs through marker-assisted selection for traits of growth, quality and carcass yield, body composition, and meat quality.

\section{ACKNOWLEDGMENTS}

A.M. Felício and C. Boschiero received scholarships from the National Council for Scientific and Technological Development, Brazil (CNPq). J.C.C. Balieiro, J.B.S. Ferraz, A.S.A.M.T. Moura, and L.L. Coutinho are recipients of productivity scholarships from CNPq. Research supported by Embrapa/Agricultural Technology Development Project for Brazil (PRODETAB).

\section{REFERENCES}

Aigner A, Butscheid M, Kunkel P, Krause E, et al. (2001). An FGF-binding protein (FGF-BP) exerts its biological function by parallel paracrine stimulation of tumor cell and endothelial cell proliferation through FGF-2 release. Int. J. Cancer 92: 510-517.

Ambo M, Moura AS, Ledur MC, Pinto LF, et al. (2009). Quantitative trait loci for performance traits in a broiler x layer cross. Anim. Genet. 40: 200-208.

Ankra-Badu GA, Shriner D, Le Bihan-Duval E, Mignon-Grasteau S, et al. (2010). Mapping main, epistatic and sexspecific QTL for body composition in a chicken population divergently selected for low or high growth rate. $B M C$ Genomics 11: 107

Anthony NB (1998). A review of genetic practices in poultry: efforts to improve meat quality. J. Muscle Food 9: 25-33.

Barbut S (1997). Occurrence of pale soft exudative meat in mature turkey hens. Br. Poult. Sci. 38: 74-77.

Baron EE, Moura AS, Ledur MC, Pinto LF, et al. (2010). QTL for percentage of carcass and carcass parts in a broiler x layer cross. Anim. Genet. [Ahead of Print].

Beer HD, Bittner M, Niklaus G, Munding C, et al. (2005). The fibroblast growth factor binding protein is a novel interaction partner of FGF-7, FGF-10 and FGF-22 and regulates FGF activity: implications for epithelial repair. Oncogene 24: 5269-5277.

Berri C, Le Bihan-Duval E, Debut M, Sante-Lhoutellier V, et al. (2007). Consequence of muscle hypertrophy on characteristics of Pectoralis major muscle and breast meat quality of broiler chickens. J. Anim. Sci. 85: 2005-2011.

Dekkers JC (2004). Commercial application of marker- and gene-assisted selection in livestock: strategies and lessons. $J$. Anim. Sci. 82 (E-Suppl): E313-E328.

Dransfield E and Sosnicki AA (1999). Relationship between muscle growth and poultry meat quality. Poult. Sci. 78: 743-746.

Ewing B and Green P (1998). Base-calling of automated sequencer traces using Phred. II. Error probabilities. Genome Res. 8: 186-194.

Falconer DS and Mackay TFC (2001). Introducción a la Genética Cuantitativa. $4^{a}$ ed. Acribia, Zaragoza.

Gaya LG, Ferraz JB, Rezende FM, Mourao GB, et al. (2006). Heritability and genetic correlation estimates for performance and carcass and body composition traits in a male broiler line. Poult. Sci. 85: 837-843.

Gaya LG, Mourão GB, Ferraz JBS, Mattos EC, et al. (2011). Estimates of heritability and genetic correlations for meat quality traits in broilers. Sci. Agric. 68: 620-625.

Gibby KA, McDonnell K, Schmidt MO and Wellstein A (2009). A distinct role for secreted fibroblast growth factorbinding proteins in development. Proc. Natl. Acad. Sci. U. S. A. 106: 8585-8590.

Gordon D, Abajian C and Green P (1998). Consed: a graphical tool for sequence finishing. Genome Res. 8: 195-202.

Kastner S, Elias MC, Rivera AJ and Yablonka-Reuveni Z (2000). Gene expression patterns of the fibroblast growth factors and their receptors during myogenesis of rat satellite cells. J. Histochem. Cytochem. 48: 1079-1096.

Le Bihan-Duval E, Berri C, Baeza E, Sante V, et al. (2003). Genetic parameters of meat technological quality traits in a grand-parental commercial line of turkey. Genet. Sel. Evol. 35: 623-635.

Le Bihan-Duval E, Debut M, Berri CM, Sellier N, et al. (2008). Chicken meat quality: genetic variability and relationship 
with growth and muscle characteristics. BMC Genet. 9: 53 .

Marie PJ, Debiais F and Hay E (2002). Regulation of human cranial osteoblast phenotype by FGF-2, FGFR-2 and BMP-2 signaling. Histol. Histopathol. 17: 877-885.

Nassar MK, Goraga ZS and Brockmann GA (2012). Quantitative trait loci segregating in crosses between New Hampshire and White Leghorn chicken lines: II. Muscle weight and carcass composition. Anim. Genet. [Ahead of Print].

Nones K, Ledur MC, Zanella EL, Klein C, et al. (2012). Quantitative trait loci associated with chemical composition of the chicken carcass. Anim. Genet. 43: 570-576.

Park GB, Moon SS, Ko YD, Ha JK, et al. (2002). Influence of slaughter weight and sex on yield and quality grades of Hanwoo (Korean native cattle) carcasses. J. Anim. Sci. 80: 129-136.

Rosário MF, Ledur MC, Moura ASAMT, Coutinho LL, et al. (2009). Genotypic characterization of microsatellite markers in broiler and layer selected chicken lines and their reciprocal Fis. Sci. Agric. 66: 150-158.

SAS (2004). SAS/STAT User's Guide: Version 9.1. SAS Institute, Cary.

Schmid M, Nanda I, Hoehn H, Schartl M, et al. (2005). Second report on chicken genes and chromosomes. Cytogenet. Genome Res. 109: 415-479.

Stephens M, Smith NJ and Donnelly P (2001). A new statistical method for haplotype reconstruction from population data. Am. J. Hum. Genet. 68: 978-989.

Tassi E, Al-Attar A, Aigner A, Swift MR, et al. (2001). Enhancement of fibroblast growth factor (FGF) activity by an FGF-binding protein. J. Biol. Chem. 276: 40247-40253.

Voorrips RE (2002). MapChart Software for the graphical presentation of linkage maps and QTLs. J. Heredity 93: 77-78.

Wu DQ, Kan MK, Sato GH, Okamoto T, et al. (1991). Characterization and molecular cloning of a putative binding protein for heparin-binding growth factors. J. Biol. Chem. 266: 16778-16785.

Yang A, Emmerson DA, Dunnington EA and Siegel PB (1999). Heterosis and developmental stability of body and organ weights at hatch for parental line broiler breeders and specific crosses among them. Poult. Sci. 78: 942-948. 